\title{
Impact of Flood Disasters on Taiwan in the Last Quarter Century
}

\author{
WEI-HSIEN TENG ${ }^{1, \star}$, MING-HSI HSU ${ }^{2}$, CHUNG-HSING WU $^{3}$ and \\ ALBERT S. CHEN ${ }^{4}$ \\ ${ }^{1}$ Department of Architecture, National United University, \#1, Lien-Kung, Kung-Ching Li, \\ Miaoli 360, Taiwan, ROC; ${ }^{2}$ Department of Bioenvironmental Systems Engineering, National \\ Taiwan University, Taipei, Taiwan, ROC; ${ }^{3}$ Department of Safety, College of Engineering \& \\ Science, Health \& Environmental Engineering, National United University, Taiwan, ROC; \\ ${ }^{4}$ National Science and Technology Center for Disaster Reduction, Taiwan, Taipei, ROC
}

\begin{abstract}
The increasing natural disasters, especially floods during the last quarter century, are raising the economic losses in Taiwan. The most severe hazard in Taiwan is flooding induced by typhoons and storms in summer and autumn. By comparing the rivers around the world, the ones in Taiwan have the steepest slopes, the largest discharge per unit drainage area, and the shortest time of concentrations. Rapid urbanization without proper land uses managements usually worsen the flood problems. Consequently, flood hazards mitigation has become the most essential task for Taiwan to deal with. Although the government keeps improving flood defense structures, the flood damage grows continuously. In this article, possible flood mitigation strategies are identified for coping with complex environmental and social decisions with flood risk involved.
\end{abstract}

Key words: Taiwan, flood mitigation, flood hazards, urban development, inundation potential

\section{Introduction}

Taiwan is an island located between Japan and the Philippines in the Western Pacific with a total area of $36,000 \mathrm{~km}^{2}$. The Tropic of Cancer passes through the southern part of Taiwan. The island is long and narrow with the Central Mountain Range in the middle. The mountain regions with elevations above $1000 \mathrm{~m}$ occupies $32 \%$ area of the island, hills and plateaus between $100 \mathrm{~m}$ and $1,000 \mathrm{~m}$ cover $31 \%$, and the rests are plains with elevations under $100 \mathrm{~m}$. Most of the mountain regions in Taiwan are sedimentary and metamorphic rocks. The geologic conditions are highly weathered and breakable. Accompanying with the intensive rainfalls, rapid flows, and frequent earthquakes, severe erosion often occurs and affects the stability of hillsides.

Taiwan is situated on typhoon tracks with high temperatures and heavy rainfalls. There were 350 typhoons and more than 1000 storms that

^ Author for correspondence: E-mail: wsteng@nuu.edu.tw 
attacked Taiwan in the past century, and led to severe flood disasters. The annual average precipitation is $2500 \mathrm{~mm}$ and reaches $3000-5000 \mathrm{~mm}$ in the mountain regions. The torrential rainfalls accompanied with typhoons concentrate in the summer and autumn seasons. In 1996, Typhoon Herb triggered a storm with maximum accumulated precipitation that reached $160 \mathrm{~mm} / \mathrm{h}$ and $1748 \mathrm{~mm} /$ day. The maximum daily rainfall during the event was $93.4 \%$ of the world record $(1870 \mathrm{~mm})$ and approximately 1.6 times observed data in Japan (Hsu et al., 2002).

Several floods that affected Taiwan have attracted great attention throughout the world during the last quarter century. For example, the floods on the Danshuei River and its tributaries (Taipei City and Taipei County, 1987, 1997, 2001), on Pachang Creek (Chiyi County, 1988), and in southern Taiwan (Kaohsiung City, 1997, 2001). According to the historical records from the Ministry of Interior Affairs (MOIA), the floods in the last 25 years damaged approximately 3000 buildings with losses of 518 million US dollars, which is approximately 4.6 times losses by fire damage.

The Water Resources Agency (WRA) of the Ministry of Economic Affairs (MOEA) has devoted a great effort to flood defense structures, such as levee construction, dredging, flood diversion, flood detention, watershed management and drainage improvement. The total budget reached 10 billion US dollars and almost $85 \%$ of the flood works had been carried out in the first 20 years (1977-1996).

One famous structural works for flood damage reduction is the Taipei Metropolitan Flood Mitigation Project (TMFMP), which includes building the Erchong diversion channel that diverts $6500 \mathrm{~m}^{3} / \mathrm{s}$ of upstream flood water from the $25,000 \mathrm{~m}^{3} / \mathrm{s}$ design flow of the Danshuei River. Through the 15-year construction from 1982 to 1996 with a total budget 3.3 billion US dollars, the TMFMP was composed of three phases. The budget of each phase is shown in Table I. The major works of the TMFMP were building river levees, drainage system, diversion systems, and land acquisition. Benefits of the works included reducing the flood stage of Danshuei main channel, avoiding redesigning of bridges and relocating buildings in downtown, and enhancing basin wide flood protection.

The engineering costs of the government for flood hazards mitigation in recent years are shown in Table II. The yearly cost has been greatly increased since 1991, in summary, $49 \%$ of the budgets are spent for building river levees. Although, the water authority keeps maintaining the existing flood structures and constructing new ones, the flood damages are growing, instead of decreasing, in proportion to the expenditure that shown in Table III. One of the possible reasons is the structural measures in regions with high flood potential usually mislead the public awareness of flood risk. Subsequent developments often aggravate the flood problems and require more investments for solving. 
Table 1. Statistics of engineering costs for Taipei metropolitan flood mitigation work. Unit: (US \$ million)

\begin{tabular}{llrr}
\hline Phase & Items & Cost & Total \\
\hline I (1982-1984) & River levees & 50.9 & 282.8 \\
& Drainage systems & 21.3 & \\
& Diversion systems & 41.4 & \\
& Land acquisitions & 169.2 & 181.6 \\
II (1985-1987) & River levees & 37.5 & \\
& Drainage systems & 57.2 & \\
& Diversion systems & 30.6 & 2845.8 \\
III (1988-1996) & Conveyance systems & 56.3 & \\
& River levees and water gates & 1710.2 & \\
& Drainage systems & 334.3 & \\
& Diversion systems & 94.6 & \\
& River refinements & 150.3 & \\
& Interest & 496.6 & 59.8 \\
Total & Others & US $\$ 3.3$ billion & \\
\hline
\end{tabular}

Engineering cost data provided by The 10th River Bureau, WRA.

In recent years, flood reduction and prevention in Taiwan have introduced non-structural efforts, such as flood alert and warning system. A flood damage alert system for the island and a flood warning system for Danshuei River Basin have been established, which combines the simultaneous observatory precipitation data and rainfall forecast information that provided by the Central Weather Bureau (CWB), and the inundation potential database provided by the National Science Council (NSC). Based on the system, a reliable flood-disaster scenarios simulating module has been developed and applied to properly integrate the hydrological information with related hazard prevention technology. The simulated results can provide essential and quantitative information (e.g., inundation depths and areas) to assist the planning of flood insurance and emergency response measures, such as choosing the shelters and routes for emergency evacuation.

The heavy loss of life as well as the unprecedented damage to properties and infrastructures induced by floods during the years 1977 and 2001 forced the government to take serious note of the losses and initiate appropriate measures for the reduction of the impact of floods. Consequently, the National Science and Technology Program for Hazard Mitigation (NAPHM) started in 1998 to identify the flood potential areas for flood hazard mitigation in Taiwan. This program is a collaboration between 
Table II. Statistics of engineering costs for flood hazards mitigation. Unit: (US \$ million)

\begin{tabular}{|c|c|c|c|c|c|c|}
\hline Year & $\begin{array}{l}\text { River } \\
\text { levee }\end{array}$ & $\begin{array}{l}\text { Irrigation \& } \\
\text { drainage }\end{array}$ & Sea-dike & $\begin{array}{l}\text { Urban } \\
\text { drainage }\end{array}$ & $\begin{array}{l}\text { Reservoirs \& } \\
\text { dams }\end{array}$ & Total \\
\hline 1977 & 14.0 & 22.4 & 2.6 & - & 4.8 & 43.9 \\
\hline 1978 & 13.0 & 14.7 & 3.0 & 7.6 & 2.8 & 41.2 \\
\hline 1979 & 15.1 & 10.0 & 3.9 & 12.0 & 3.2 & 44.2 \\
\hline 1980 & 21.0 & 11.8 & 5.4 & 9.5 & 6.5 & 54.2 \\
\hline 1981 & 56.1 & 17.8 & 10.5 & 13.1 & 9.9 & 107.5 \\
\hline 1982 & 81.2 & 20.9 & 6.6 & 13.8 & 37.3 & 159.8 \\
\hline 1983 & 40.4 & 41.1 & 7.0 & 15.1 & 21.3 & 124.9 \\
\hline 1984 & 68.0 & 36.6 & 8.8 & 15.4 & 37.8 & 166.7 \\
\hline 1985 & 40.5 & 27.4 & 9.0 & 17.4 & 0.9 & 95.1 \\
\hline 1986 & 55.6 & 49.1 & 10.9 & 15.5 & 23.7 & 154.8 \\
\hline 1987 & 57.5 & 21.6 & 12.2 & 19.4 & 5.8 & 116.5 \\
\hline 1988 & 42.0 & 31.0 & 8.5 & 21.3 & 23.3 & 126.0 \\
\hline 1989 & 62.5 & 47.8 & 12.4 & 26.3 & 9.9 & 158.9 \\
\hline 1990 & 61.8 & 61.9 & 10.1 & 48.0 & 101.8 & 283.6 \\
\hline 1991 & 377.2 & 75.4 & 48.1 & 50.8 & 127.3 & 678.8 \\
\hline 1992 & 274.1 & 68.9 & 23.2 & 51.1 & 171.1 & 588.4 \\
\hline 1993 & 346.5 & 73.9 & 41.7 & 70.0 & 18.4 & 550.5 \\
\hline 1994 & 1425.5 & 47.3 & 29.8 & 115.7 & 175.4 & 1793.7 \\
\hline 1995 & 285.8 & 69.0 & 23.4 & 204.4 & 148.7 & 731.3 \\
\hline 1996 & 182.7 & 55.8 & 25.1 & 142.5 & 248.0 & 654.1 \\
\hline 1997 & 210.2 & 73.1 & 17.0 & 151.4 & 110.3 & 561.9 \\
\hline 1998 & 383.2 & 53.6 & 32.9 & 168.8 & 155.7 & 794.1 \\
\hline 1999 & 203.8 & 72.8 & 19.2 & 133.1 & 124.7 & 553.7 \\
\hline 2000 & 351.1 & 16.4 & 28.5 & 76.6 & 235.6 & 708.2 \\
\hline 2001 & 241.0 & 200.6 & 23.5 & 54.2 & 131.3 & 650.6 \\
\hline Total & 4909.8 & 1220.8 & 423.3 & 1453.1 & 1935.6 & 9942.6 \\
\hline
\end{tabular}

Engineering cost data provide by WRA.

Table III. Casualties and losses caused by Taiwan flood disasters in the last 10 years

\begin{tabular}{lllllllllllll}
\hline Year & 1991 & 1992 & 1993 & 1994 & 1995 & 1996 & 1997 & 1998 & 1999 & 2000 & 2001 \\
\hline Casualties \& the missing $^{\text {a }}$ & 31 & 15 & 36 & 28 & 35 & 73 & 28 & 17 & 54 & 89 & 178 \\
Losses (US \$ million) $^{b}$ & 32.4 & 22.9 & 26.2 & 15.1 & 13.8 & 19.4 & 24.2 & 33.7 & 28.8 & 36.1 & 55.7 \\
\hline
\end{tabular}

${ }^{a}$ Casualty data provided by National Fire Agency, ROC (2001).

${ }^{\mathrm{b}}$ Losses data provided by WRA, Council of Agriculture and National Tax Administration. 
research institutes, central and local government agencies and private organizations to implement the program.

The major factors relate to flood disasters in Taiwan, such as characteristics of rivers in Taiwan, the global problem of climate change, and improper urban development, are identified in the following sections. In addition, several historical flood disasters are also described. The paper concludes by proposing 10 possible flood hazards mitigation strategies.

\section{Characteristics of Rivers in Taiwan}

The 129 rivers in Taiwan have short lengths and steep bed slopes. The upstream catchments of most rivers have bed slopes steeper than $1 / 100$, whereas the downstream ones decrease to $1 / 200-1 / 500$, with only 5 rivers being milder than $1 / 500$. There are only 9 rivers that have a watershed area exceeding $100 \mathrm{~km}^{2}$.

\subsection{GEOGRAPHICAL CHARACTERISTICS}

Most watersheds in Taiwan are formed by fragile sandstone and shale. Downstream reaches of the rivers have heavy deposits flushed from the poor geologic upstream catchments by intensive rainfalls. The sediment concentrations in rivers are large and composed with some special geologic structures such as mudstone and conglomerate that can easily become mudflows. The huge deposits are difficult to be removed and often result in serious floods. These characteristics of rivers lead to huge flow peaks and rapid rising. Moreover, the uneven distribution of concentrated rainfall and short river length induce worse flow conditions in Taiwan.

\subsection{HYDROLOGICAL CHARACTERISTICS}

The annual rainfall in Taiwan reaches $2500 \mathrm{~mm}$, which is 2.5 times the world average. However, $75 \%$ of the annual rainfall concentrates in the period from May through October. There were 350 typhoons, and over 1000 storms in Taiwan in the last century. The statistics show that losses due to natural disasters reached 365 million US dollars from 1983 to 1995. The amount is approximately 4.6 times fire damages in the same period. The peak discharge per unit drainage area in Taiwan is the largest in the world. For instance, the specific peak discharge of the Choshui River is 450 times that of the Yangtze River in China and 25 times that of the Sinno River in Japan. The comparison of specific peak discharges in the world is shown in Figure 1, and all of the rivers whose specific peak discharges are larger than the Sinno River's are in Taiwan. 


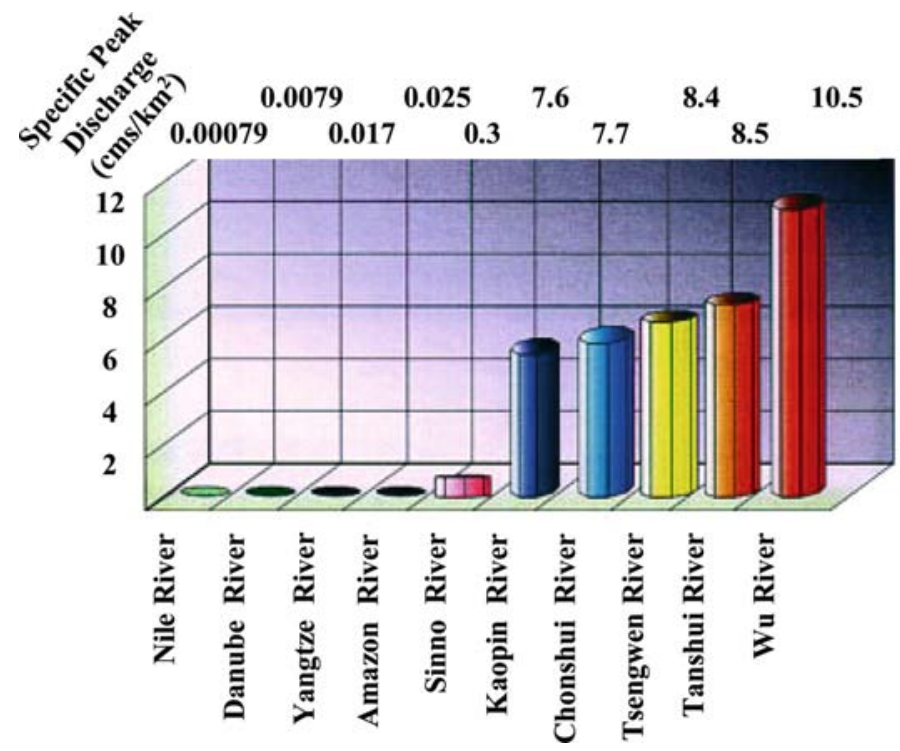

Figure 1. Comparison of specific peak discharges in rivers around the world ( $\mathrm{cms}$ is $\left.7 \mathrm{~m}^{3} / \mathrm{s}\right)$.

\section{Problem of Climate Change}

In the last century, Taiwan experienced an island-wide warming trend $\left(1.0-1.4{ }^{\circ} \mathrm{C} / 100\right.$ years). Both the annual and daily temperature ranges have been increased. (Manitoba Water Commission, 1998) The annual accumulated rainfall of the Taipei station in 2002 is $268 \mathrm{~mm}$ more than the one in 1899, but the rainy days in 2002 is 28 days less than the one in 1899 . Moreover, the highest rainfall intensity occurred in September between 1970 and 1985, and advanced to October during 1986-2000. Flood catastrophes are becoming more frequent and more intensive. If the climatic change takes place as predicted, a further dramatic deterioration in the risk situation must be expected (Woodcock, 1989).

\section{Improper Urban Development}

The analysis of countrywide flood disaster locations shows that it is highly related to improper urban development. A famous example is the quick urbanization of Sijhih City in northern Taiwan. Owing to the increasing migration into the region, the urban area expanded quickly. Unfortunately, the inundation potential was not considered in urban planning, which resulted in over-development along the Keelung River. Some buildings even occupy the floodplains and increase the flood risks (Ma et al., 1999). 
Highly populated and vulnerable areas, with potential natural disasters, have been located and inspected in Taiwan. Recent rains in several parts of the country caused havoc by way of floods in low lands including Taipei City. Similarly, the typhoons that attacked northern Taiwan in 1998 and 2001 had generated severe destruction to human lives and property. For any active intervention of disaster preparedness to be successful, it is necessary to identify the major areas of vulnerability for each hazard. In such a task, it is very important to carry out hazard potential zone mapping with a view to identifying the areas and the magnitude of the risk assessment in order to work out the cost of damages.

\section{Severe Damage and Lessons in Taiwan}

The flood in August 7th, 1959, caused unprecedented damage and 1300 casualties in Taiwan. At former currency values, the total loss was nearly 97 million US dollars. Typhoon Gloria invaded Taiwan in September 1963 and the people on the island suffered 40 million US dollars loss and more than 600 casualties. In short, there were approximately 3000 casualties, and the total loss exceeded 214 million during 1950-1970 (Hsu and Chen, 2002).

In the last 15 years, catastrophic flood disasters recurred continually. In October 1987, Typhoon Lynn passed the northern part of the island and caused more than 1000 ha in area in Taipei City to be flooded in the lowland along the Keelung River. Nine years later, Banciao City, Jhonghe City, Yonghe City, and Sijhih City in Taipei County, as well as, Cidu District in Keelung City suffered severe flood disasters and 58 million US dollars in losses in Typhoon Herb. In 1998, Typhoon Zeb invaded northern Taiwan successively and flooded 34 communities with 3 people drowned along the Danshuei River. The most severe flood disaster site is located at Sijhih in Taipei County. More than 1000 households were inundated and 50,000 households suffered electricity failure (National Fire Agency, ROC, 2001).

On July 18th, 2000, a heavy rainfall occurred in the upstream watershed of Pachang Creek and induced a rapidly huge flow peak. Unfortunately, 4 professional hydraulic workers were flushed away. Three months later, Sijhih was inundated again by Typhoon Xangsane and nearly $2 / 3$ of the urban area was flooded. Respectively, Cidu District and Nuannuan District in Keelung City suffered catastrophic floods, which caused 64 casualties, 65 injured, 25 disappearances and inestimable loss of agriculture, fishery and property (Teng et al., 2000).

Southern Taiwan did not escape from the impact of flood disasters. Typhoon Tanmei caused severe flooding in Kaohsiung City where nearly $90 \%$ of basements were submerged by the flood. There were 5 casualties 


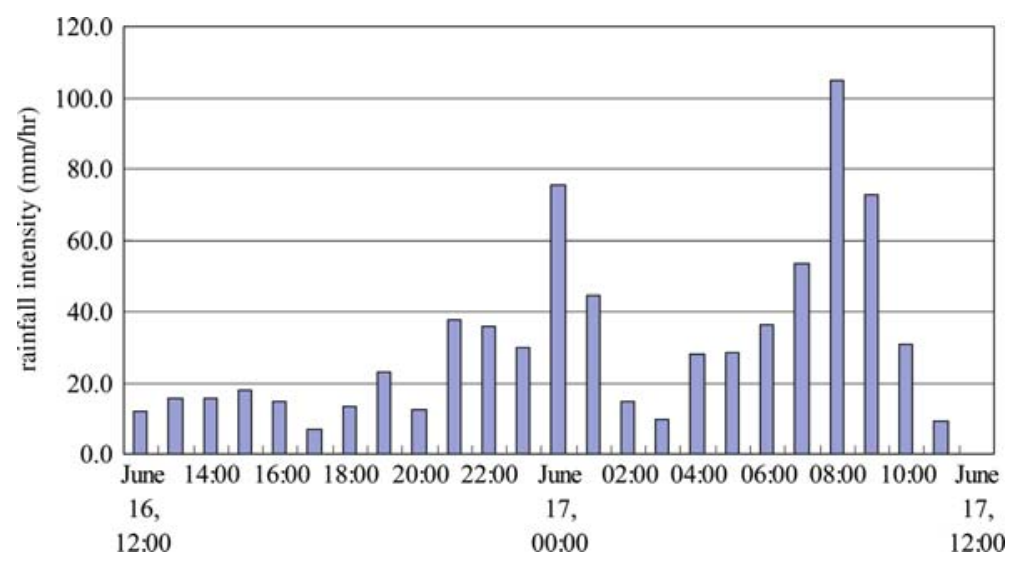

Figure 2. Historical rainfall records of Nan-Gun rain gage in Typhoon Nali.

found in 3 basements and huge loss of property. Two months later, another severe flood disaster in Taiwan attracted worldwide attention.

On September 17th, 2001, the mountains in northeastern Taiwan suffered from a heavy rainfall brought by Typhoon Nari. According to the CWB's report, typhoon came through the Keelung River from the sea with threatening rain clouds that caused torrential rainfall. In the Nankang District of Taipei, the rainfall intensity increased from 4 a.m. (shown in Figure 2), the hourly rain amounted to $105 \mathrm{~mm}$ at 8 a.m. and $73 \mathrm{~mm}$ at 9 a.m., respectively. The $12-\mathrm{h}$ rainfall from 4 a.m. to 4 p.m. amounted to $530 \mathrm{~mm}$.

This heavy rainfall and the consequent overflow from the Keelung River caused the inundation of a wide area of Taipei city, which is located in the northern part of Taiwan. The flood intruded into the substructure space, namely, the rapid transit system, the subway stations, and the basements in buildings and underground shopping malls, which caused heavy damages. There were 104 casualties or missing persons in this storm. The losses were so huge at the Taipei City government and most experts believed that the direct losses should be more than 20 million US dollars. Figure 3 shows numerous cars submerged in Typhoon Nali storm and people dealing with the enormous waste after the flood in Figure 4 (Taipei City Government, 2001).

\section{Government's Following-up Flood Hazards Mitigation Measures}

Following the devastating floods of 2001 in the Danshuei River Basin, the Council for Economic Planning and Development (CEPD), ROC asked the WRA to investigate the causes and effects of flooding in Taiwan and 


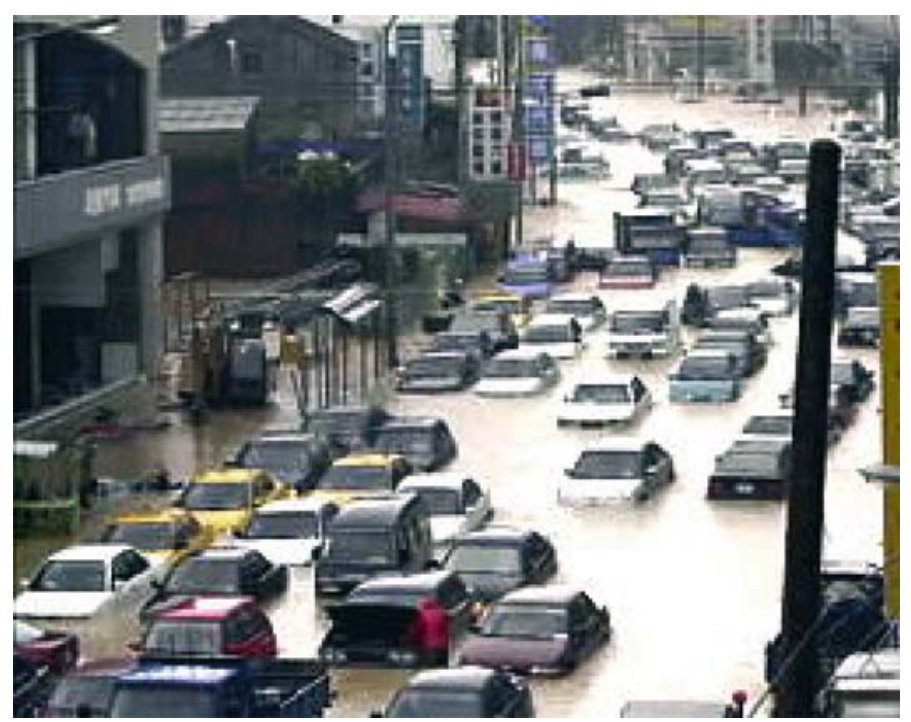

Figure 3. Numerous cars were submerged in Typhoon Nali.

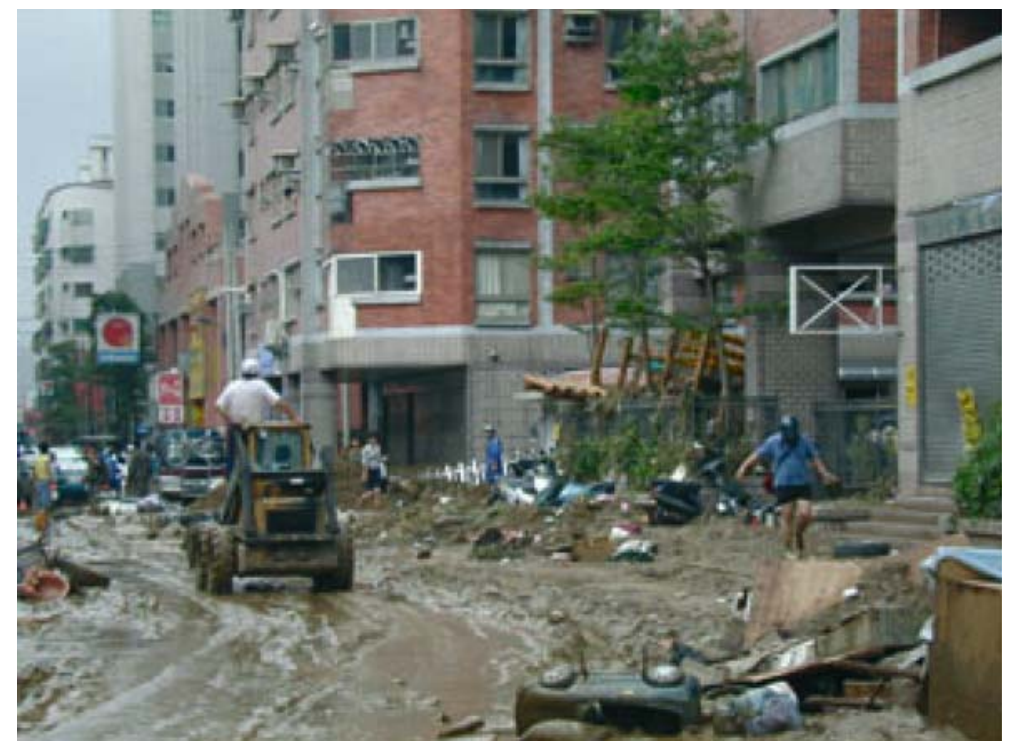

Figure 4. People deal with enormous waste after Typhoon Nali.

to provide them with an interim report by the end of 2001. In December 2001, the WRA reported to the CEPD on interim measures that should be undertaken to prepare for possible floods in the short-term. The interim report cautioned against complacency, noting that major flooding could 
occur at any time, and made 32 recommendations regarding flood forecasting, monitoring improvements, emergency measures and planning, environmental concerns, and floodplain management including zoning, legislation, and enforcement. The CEPD asked the WRA to report on Executive Yuan's actions that were covered by the 40 recommendations. The WRA reported in July 2002. Ten major follow-up measures on flood hazards mitigation are shown as follows (Water Resources Agency, ROC, 2000, 2003):

1. In the evaluation of short- and long-term flood damage reduction measures with communities, the WRA stresses the remaining risk, even after the measures have been implemented.

2. The Institute of Planning and Hydraulic Research has funded a Regional Project Impact initiative in the major river basins to enhance public awareness in these basins. In addition, the Ministry of Financial Affairs has a marketing campaign to strengthen the feasibility study of flood insurance policies in Taiwan.

3. The WRA and several other central agencies, and local governments have met to discuss long-range recovery issues, which included coordination with the counties on preparedness and mitigation.

4. Increased contacts on a regular basis among the emergency management organizations throughout the basin should be a priority in order to establish better appreciation for the manner in which each operates during an emergency.

5. Update and enhance existing forecast models based on 2001 data and experience, focusing specifically on improvements that can be incorporated in basin-wide forecasts prior to the following flood seasons. In particular, the rating curve of the Danshuei River extensions should be undertaken as soon as possible.

6. Simplify and clarify communication between flood forecasters and those with local flood emergency responsibility, throughout the basin. The dissemination of forecast information to the public through the media should be simple and the variables inherent in those forecasts easily understood.

7. Plans to implement new flood mitigation and flood-proofing measures by ecological methods for individuals and communities - if sound in economic, environmental, engineering and social terms - should continue as rapidly as possible. All such measures, whether by government or individuals, should be coordinated and examined to determine possible damage to others within the basin.

8. Develop a consolidated database containing hydrometric, climatic, topographical and other technical data within the basin. The data are needed to improve forecasting and modeling capability. 
9. Document the 2001 overland flow areas within the flooding basins, high-water marks and head losses, wind effects, timing and extent of road or dike breaches and blow-outs, and data networks used during the flood. In addition, document the shape, elevation and alignment of roads, dikes, levees and drains, including the size of bridge and roadway openings.

10. Develop hydraulic models for the Red River and its major tributaries, capable of being expanded for use in forecasting and analyzing overland flooding, as well as for floodplain management.

\section{Flood Hazards Mitigation Strategies}

The flood mitigation measures given by government sectors contain policy, guidelines, and planning which are employed to remove blind sides of past flood mitigation measures in short term. However, effective, detail, and comprehensive flood mitigation strategies in middle or long term require integrated structure and non-structure measures in one comprehensive system. Therefore, it is the purpose of this paper to propose flood hazards mitigation strategies which are based on the aforementioned measures given by the government sectors (Li et al., 2002).

\subsection{FLOOD PROTECTION MEASURES}

Most cities were developed adjacent to rivers; dikes and flood levees were commonly used to reduce flood damages due to extreme rainfall intensity and excessive flood discharges (United States Geological Survey, 1986). More than $70 \%$ of the rivers have had their flood control facilities completed, such as the Danshuei River, Tali Creek and New Huwei Creek. Future design planning should take ecologic methods into consideration, as shown in Figure 5, in order to ensure sustainable use. Protection levels of flood prevention measures are shown in Table IV. The dredging or channel improvements should be employed to increase conveying capacity in aggraded river reaches. According the WAR planning, there are $443 \mathrm{~km}$ of river dikes that need to be constructed in the next 6 years.

\subsection{IMPROVEMENT MEASURES FOR URBAN AREAS}

Flow diversions should be used in developed areas where the main channel could not be expanded to convey the entire design flow. The Erchong Diversion Channel of the Danshuei River flood control project is a typical example.

Though river conveyance can be increased by channel relocation or meander cutoff, the design should consider the preservation of the flood 


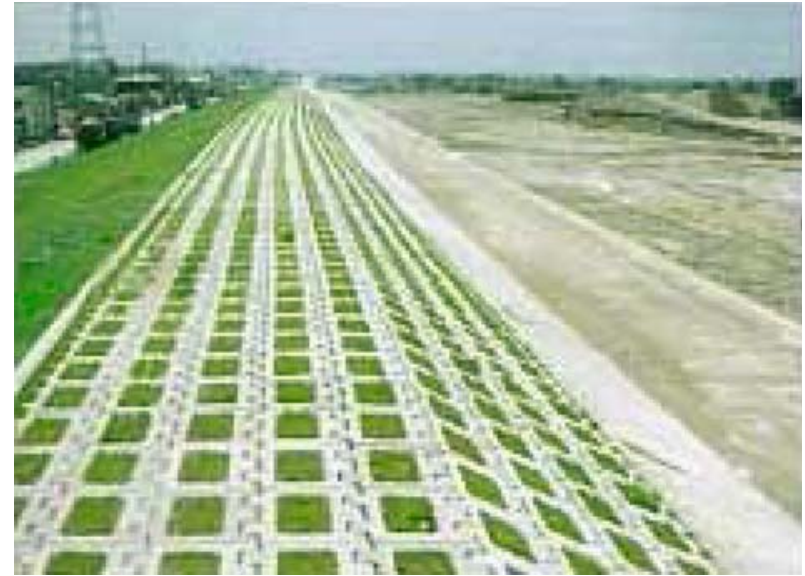

Figure 5. Dike construction employing ecology methods.

Table IV. Protection levels of flood prevention measures

\begin{tabular}{lll}
\hline Facility & Classification & Protection (return period in years) \\
\hline Rivers & Taipei Metropolitan & 200 \\
& Major rivers & 100 \\
& Secondary rivers & 50 \\
& Minor rivers & 20 \\
Coastal levee & All levels & When no waves overflow or cause splash damage \\
Regional drainage & All drainage systems $5-10$ \\
Urban drainage & Villages & 3 \\
& Towns & 3 \\
& Cities & 5 \\
& Counties & 5 \\
& Taipei City & 5 \\
& Kaoshiung City & 5
\end{tabular}

Remark: Data provide by WRA.

storage capability. The relocation of the Keelung River as well as the meander cutoff along the Zhongshan Bridge section of the Keelung River have resulted in a rapid rising water stage during heavy rainfall, induced by Typhoon Nali storm, occurring in the upstream watershed of the Keelung River.

\subsection{RESERVOIR DETENTION}

There are 11 reservoirs having flood control capability in Taiwan, among them the Akongtien Reservoir which is the only one single-purposed detention 
reservoir. Flood stages in a river downstream of flood control reservoirs can be decreased through adjusting reservoir storage levels. There should be more small detention dams constructed in the upper reaches of the rivers with high flood potential downstream, in order to reduce the flow peaks.

During the period of Typhoon Herb, those 11 flood control reservoirs stored approximately 900 million cubic meters of flood flow; among them, the Feidui Reservoir (shown in Figure 6) stored 370 million cubic meter of flood flow.

\subsection{WATERSHED MANAGEMENT AND IMPROVEMENT}

Watershed management and improvement, such as forest management, wild creek improvement, gully erosion control, farmland soil conservation, can reduce soil loss and damage to hillside fields. It can also preserve water resources, reduce flood peak discharge and flood damages.

\subsection{FLOOD MITIGATION AND PREVENTION}

Land uses control through floodplain management is an effective means of flood mitigation and prevention (Abbott, 1991). Inundation areas for most of the rivers in Taiwan should be delineated to provide information for floodplain management. Developments in floodplain areas must be restricted or limited to reduce flood damage.

Future land development in areas with high vulnerability to floods should be avoided. With the inundation potential maps, the determination of land development locations can be more cost-effective. For example, areas with high flood risks can be banned from future development; while

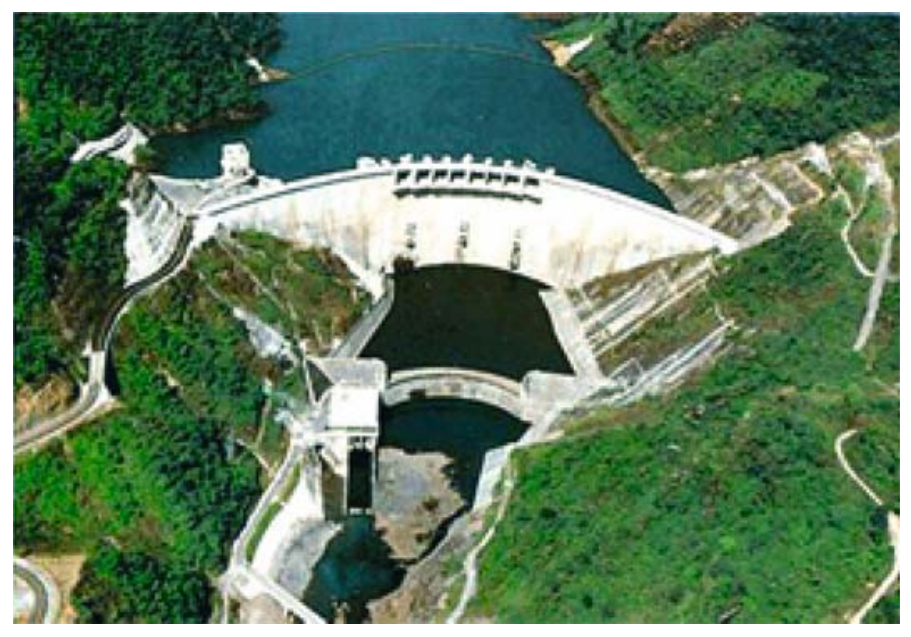

Figure 6. Overview of the Feidui reservoir in Taiwan. 
those that have been developed can be improved by imposing engineering measures. Before construction of possible measures, performance assessments should be conducted to generate inundation potential maps for evaluations. Most important of all, areas with high vulnerability to floods should be banned from future development through policy rulings. Inundation potential maps can be provided for government agents and policy makers for regulating related public policies. Constraining orders should be imposed on areas with high inundation risks. Inundation potential maps certainly provide valuable quantitative information to assist regulation and ruling of public policy.

\subsection{PLANNING OF FLOOD INSURANCE}

In the last 10 years, increased attention and concern have been focused on the impact of natural disasters, including flooding. This is particularly true in Taiwan, where disasters can devastate lives, causing millions of dollars in damages, and impact the economic viability of counties for many years following an event. Planning ahead is crucial when it comes to flood insurance. Flood damage can happen to anyone, and it is important for Taiwan to realize that damage may occur to properties that are located in highflood potential zones and those that are not. Assessing, planning and implementing flood insurance is the government's responsibility as Homeowner's Insurance does not provide coverage for flood damage now in Taiwan.

\subsection{PLANNING EMERGENCY RESPONSE MEASURES}

Inundation potential maps can be used for the planning of emergency response measures to select emergency shelters and evacuation routes. Propagation time of a peak flood wave at different inundation zones delimited in the maps can be used to estimate the emergency response time for different locations. Government agents should be trained to be capable of using basic information contained in maps for regulations and planning.

\subsection{DRAINAGE IMPROVEMENT}

The drainage systems are the most important facilities to reduce flood damages in urban areas. The improvement of drainage systems is implemented by county governments under the supervision of the WRA. A common practice for drainage improvement is to install pumping stations in low-lying areas for removing floods. Less than $35 \%$ of the drainage improvements have been completed. At the present time, drainage improvements are the most effective flood damage reduction activities, the constructions and improvements of drainage systems should be accelerated. 


\subsection{ESTABLISHMENT OF FLOOD WARNING SYSTEM}

Prevention, mitigation and relief are important measures for disaster management. The collection of flood information is the basis for establishing flood prevention systems. It is almost incomprehensible that the Danshuei River basin flood control commanding system is the only one established in Taiwan. There are more than 5 flood warning systems for different rivers that have been planned completely and should be established as soon as possible. It is anticipated that flood information management systems will include flood insurance, flood warning, damage notification and incorporation with GIS in the future to provide further capabilities.

\subsection{COASTAL PROTECTION}

It is very important to protect the long coastline in Taiwan. In addition to installing tidal stations, coastal protection and coastal dikes are the two most commonly used protection facilities. Figure 7 shows the coastal protection along Ginshan beach in Taipei County. In order to improve scenery and sustainable use of coastal resources, improvements with a natural look should be actively pursued now around Taiwan.

\section{Conclusions}

According to historical flood records, people in Taiwan must reckon with more - and larger - flood events and catastrophes in the future. For this reason, both authorities and the population must be made aware in order to take appropriate steps without delay in Taiwan. On the one hand, the people must recognize that the efforts that are being taken to combat natural hazards must continue, while, on the other hand, all levels of government must carry out the flood protection and loss minimization or

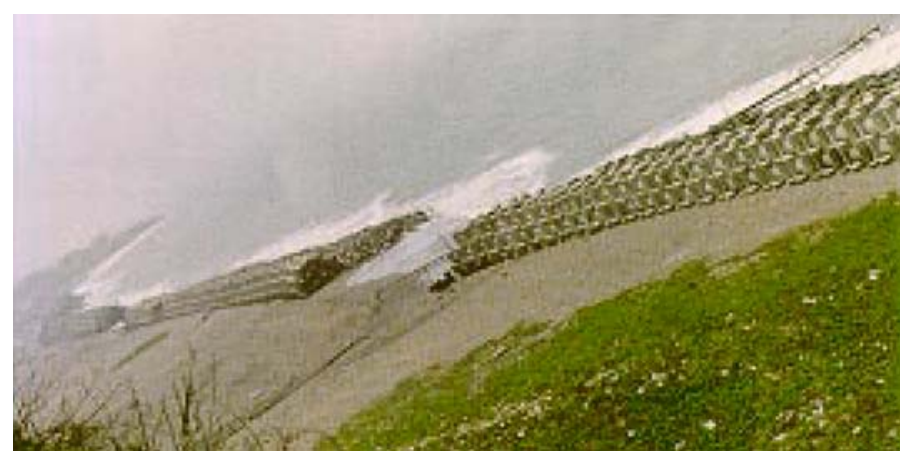

Figure 7. Coastal protection along Ginshan beach in Taipei County. 
prevention. There are many well-known and available technical, organizational and financial measures designed to reduce the flood hazards. Long-term and short-term precautions play just as large a part in this as catastrophe aid and post-event measures.

The need to make available Hazard Maps whether they are in respect to the flood hazards in the lowland or other types of natural disasters in any part of the country cannot be overemphasized, taking into consideration the high rate of vulnerability of the community to various hazards. The early availability of these maps is just as important as the awareness of the community in the use of these hazard maps.

\section{Acknowledgements}

This study was supported by the National Science and Technology Center for Disaster Reduction, and National Science Council, ROC. Valuable historical flood disasters data were provided by the Water Resources Agency, the Central Weather Bureau, the National Fire Agency, and the Taipei City Government. The authors are grateful for their considerable assistance.

\section{References}

Abbott, M. B.: 1991, Hydroinformatics, Gower Publish Company.

Hsu, H.-H. and Chen, C.-T.: 2002, Observed and projected climate change in Taiwan, Meteorol. Atmos. Phys. 79, 87-104.

Hsu, M. H., Chen, S. H., and Chang, T. J.: 2002, Dynamic inundation simulation of storm water interaction between sewer system and overland flows, J. Chin. Inst. Eng. 25(2), 171177.

Li, M. H., Hsu, M. H., Hsieh, L. S., and Teng, W. S.: 2002, Inundation potentials analysis for Tsao-Ling landslide lake formed by Chi-Chi Earthquake in Taiwan, Nat. Hazards 25, 289-303.

Ma, K. F., Lee, C. T., Tsai, Y. B., Shin, T. C., and Mori, J.: 1999, The Chi-Chi, Taiwan Earthquake: large surface displacements on an inland thrust fault, EOS, Transactions, Am. Geophys. Union 80(50), 605.

Manitoba Water Commission: 1998, An Independent Review of Actions Taken During the 1997 Red River flood. A Report to the Honourable J. Glen Cummings, Minster of Natural Resources. Manitoba Natural Resources publication.

National Fire Agency, ROC: 2001, Investigations Report of the Disasters in Taiwan after Typhoon Nali (in Chinese).

Taipei City Government: 2001, Report of Investigations into Measures for the Reduction of the Disasters in Taipei City after Typhoon Nali, Appendix C, Flood Disasters Analysis (in Chinese).

Teng, W. H., Hsu, M. H., and Chang, S. Y.: 2000, Damage to hydraulic facilities from the Chi-Chi (Taiwan) Earthquake, J. Chin. Inst. Eng. 23(4), 385-394.

United States Geological Survey: 1986, National Water Summary, Water Supply Paper 2325. 
Water Resources Agency, ROC: 2001, Investigations Report of the Disasters in Taiwan after Typhoon Nali (in Chinese).

Water Resources Agency, ROC: 2000, Annual Survey of Hydrology Information in Taiwan (in Chinese).

Woodcock, D. W.: 1989, Climate sensitivity of wood-anatomical features in a ring-porous oak (Quercus macrocarpa), Can. J. Forest Res. 19, 639-644. 